\title{
Türkiye Sıcaklık Ekstremlerindeki Değişkenlikler
}

\section{Variations in Temperature Extremes in Turkey}

\author{
Zahide ACAR-DENIZ1', Barbaros GÖNENÇGIL ${ }^{2}$
}

${ }^{1}$ Çanakkale Onsekiz Mart Üniversitesi, Fen-Edebiyat Fakültesi, Coğrafya Bölümü, Çanakkale, Türkiye

${ }^{2}$ İstanbul Üniversitesi, Edebiyat Fakültesi, Coğrafya Bölümü, İstanbul, Türkiye

\section{öz}

Çalışma alanı $36^{\circ}-42^{\circ}$ Kuzey enlemleri ile $26^{\circ}-45^{\circ}$ Doğu boylamları arasında yer alır. Çalışmada kullanılan sıcaklık verileri, Meteoroloji Genel Müdürlüğü (MGM) tarafından sağlanmıştır. Veriler, 156 istasyona ait günlük minimum, maksimum ve ortalama sıcaklıklardan oluşmaktadır. Günlük veriler, kış ve yaz dönemindeki tanımlayıcı istatistikleri açıklamak için aylık verilere ve mevsimlik verilere dönüştürülmüştür. Sıcaklıklardaki ekstrem olayların belirlenebilmesi için kullanılan veri setleri günlük ve orijinal verilerden oluşmaktadır.

Bu çalışmanın amacı, Türkiye'nin yaz ve kış mevsimlerindeki ekstrem sıcaklıkların alansal ve zamansal dağılış desenlerini anlamaktır. Sıcaklık verilerinde herhangi bir önemli değişikliğin olup olmadığına karar vermek için Kruskal-Wallis (K-W) sınaması uygulanmıştır. Verilerdeki değişkenliğin doğası ve büyüklüğünü anlamak için Mann-Kendall (M-K) sıra ilişki katsayısı yöntemi kullanıldı. Sıcaklık verilerine uygulanan Kruskal-Wallis test istatistiğine göre, istasyonların çoğunda yaz mevsiminde istatistiksel olarak anlamlı inhomojenlik gözlenmiştir.

M-K test istatistiğine göre, Türkiye genelinde sıcaklık ekstremlerinde (yaz günü, tropikal gece, ekstrem sıcaklık aralığı vb.) istatistiksel olarak anlamlı bir artış bulunur.

Anahtar kelimeler: Ekstrem sıcaklık, Sıcaklık İndisi, Trend Analizi, Türkiye

\section{ABSTRACT}

The study area is located between $36^{\circ}$ to $42^{\circ} \mathrm{N}$ and $26^{\circ}$ to $45^{\circ} \mathrm{E}$. In this study, we have used the data that has been provided by the Turkish State Meteorological Service (TSMS), including the daily minimum, maximum, and average temperatures that were recorded at 156 meteorological stations. Daily data are converted into monthly and seasonal data to explain the descriptive statistics during winter and summer. Datasets that are used to determine temperature extremities comprise daily and original data.

This study aims to understand the spatial and temporal distribution patterns of extreme summer and winter temperatures in Turkey. The KruskalWallis (K-W) test is performed to determine whether any significant changes in the temperature data are observed. The Mann-Kendall (M-K) order correlation coefficient method is performed to understand the nature and magnitude of the variability in data. According to $\mathrm{K}-\mathrm{W}$ test statistics, a statistically significant inhomogeneity is observed, particularly during summer at all stations at most of the temperatures. Furthermore, according to the $\mathrm{M}-\mathrm{K}$ test statistics, a statistically significant increase in temperature extremes (i.e., during summer days, tropical nights, and extreme temperature range) is observed throughout Turkey.

Keywords: Extreme Temperature, Temperature indices, Trend analysis, Turkey 


\section{EXTENDED ABSTRACT}

In this study, spatial distribution and temporal changes during extreme temperature in Turkey are investigated, including summer days, tropical nights, extremely cool and warm days, warm days, frosty days, ice days, as well as the diurnal temperature range indices. The study area is located between $36^{\circ}$ to $42^{\circ} \mathrm{N}$ and $26^{\circ}$ to $45^{\circ} \mathrm{E}$. The data used in this study are provided by the Turkish State Meteorological Service, including the daily minimum, maximum, and average temperatures that were recorded at 156 meteorological stations. Daily data are converted into monthly and seasonal data to obtain descriptive statistics during winter and summer. Datasets that are used to determine temperature extremities comprise daily and original data.

The Kruskal-Wallis $(\mathrm{K}-\mathrm{W})$ test is performed to determine whether significant changes in the temperature data are observed. The Mann-Kendall $(\mathrm{M}-\mathrm{K})$ order correlation coefficient method is utilized to understand the nature and magnitude of the variability in data. According to $\mathrm{K}-\mathrm{W}$ test statistics, a statistically significant inhomogeneity is observed, particularly during summer at all stations at most of the temperatures. Furthermore, according to the $\mathrm{M}-\mathrm{K}$ test statistics, a statistically significant increase in temperature extremes (i.e., during summer days, tropical nights, and extreme temperature range) is observed throughout Turkey.

The most remarkable dataset of Turkey is the minimum temperatures that are observed in summer. Almost all stations exhibit an increase in the night temperatures during summer. These trends exhibit statistical significance where urban heat islands exhibit a considerable effect.

According to the results obtained in this study, Turkey has experienced a considerable change in temperature, particularly after the 1990s. An increase and decrease in indices corresponding to warm and cool/cold days, respectively, were observed in Turkey. A statistically significant increase in the summer day and tropical night temperatures in Turkey was recorded. This trend of increasing temperatures started in the late 1980s and has transformed into a strong war since the late 1990s.

Meanwhile, the number of extremely cool days has significantly decreased throughout Turkey. In the year 2010, Turkey has experienced a large number of extremely cool days. A statistically significant increase in the number of extreme warm days has been observed. Since the mid-1990s, the number of warm days has exhibited a considerable increase. Throughout Turkey, the number of frosty days has decreased. The least number of frost occurrences have been recorded in 2010. The diurnal temperature range exhibits a weak upward trend, both during winter and summer. This tendency is not statistically significant. The upward trend in winter can be explained by the increase in the minimum temperature data that has been observed during winter, corresponding to the increase in the minimum and maximum temperatures during summer.

The results obtained in terms of variability in the frequency of extreme events and temperature variations that were observed at the Mediterranean Basin are similar to those that were observed in Turkey, which is located in the Mediterranean macroclimate area.

Thus, the variations in temperature indices in Turkey are occurring in accordance with global patterns. Anthropogenic factors and processes, including urbanization, greenhouse gas emissions, and natural field damage, have resulted in temperature extremities to become more pronounced and effective. 


\section{GíRIŞ}

Yeryüzü tarihi boyunca iklimler sinüsoidal bir dalga halinde değişim göstermiştir. Bugün yaşanan süreç ise özellikle 1850'li yıllardan sonra ortaya çıkan aşırı nüfus artışı ve sanayileşmeye dayalı bir çevresel degradasyonun sonucu olarak görülse de bu durum iklimlerdeki doğal değişikliklerin veya salınımların oluşumunu engelleyebilecek ya da yönünü değiştirebilecek bir güçte değildir (Gönençgil, 2008). Öte yandan günümüzde doğal afetlerin frekansı ve şiddetindeki artışlar da iklim değiş̧ikliğinin bir göstergesi olarak kabul edilir. Bu bağlamda, kara ve deniz yüzeyi sıcaklıklarındaki artışlar ile yağış değişimleri (azalma ve artış), ekstrem olayların artması, iklim değişikliğinin şiddetini gösteren en önemli kanıtlardır.

Şüphesiz ki iklimsel değişkenlik ya da değişiklik her alanda aynı etkiyi göstermemektedir. Bazı alanların yaşanabilecek değişikliklere karşı hassasiyeti de farklılık gösterebilecektir. Her alanın aynı değişim ya da değişkenlikten farklı şekilde etkileneceği yapılan çeşitli çalışmalarla ortaya koyulmuştur. Bazı alanların hassasiyetinin yüksek olması ya da iklim değişikliğinin bir göstergesi sayılan ekstrem olaylardan etkilenebilirliğinin değişkenlik göstermesi bunun en çarpıcı örneğidir. Dünya Meteoroloji Teşkilatı (WMO) ve Uluslararası İklim Değişikliği Paneli (IPCC) raporlarına göre, Akdeniz havzası iklim değişikliğinden en çok etkilenecek olan alanlar içinde yeralır (IPCC, 2007; IPCC, 2012; WMO, 2016). Birçok çalışmada, ekstrem olayların frekanslarında yıllar arasında önemli değişimler olduğu belirlenmiştir (Acar-Deniz ve Gönençgil, 2015; Fernandez-Motes ve Rodrigo, 2012; KleinTank ve Können, 2003; Luterbacher, Dietrich, Xoplaki, Grosjean ve Wanner, 2004; Merino vd., 2017; Salman, Shahid, Ismail, Chung ve Al-Abadi, 2017). Akdeniz iklimi, yağışının büyük bir bölümünü kışın alan, buna karşılık yaz aylarının kurak geçtiği bir karaktere sahiptir. Akdeniz iklim bölgesinde yaz aylarında sıcak ve kurak dönemler egemendir. Akdeniz havzasını da etkileyen ekstrem hadiseler, hem kış hem de yaz mevsiminde sıcaklık ve yağışların alansal dağılış özellikleri bakımından Türkiye'de de sık sık yaşanan olaylar haline gelmiştir.

Türkiye hava sıcaklıklarında artış (özellikle gece sıcaklıkları) dikkat çekicidir. Özellikle son zamanlarda daha sık yaşanan sıcak-soğuk hava dalgaları, şiddetli yaz kuraklıkları sosyoekonomik açıdan önemli problemlere neden olacak düzeydedir.

\section{VERİ VE YÖNTEM}

Çalışma alanı $36^{\circ}-42^{\circ}$ Kuzey enlemleri ile $26^{\circ}-45^{\circ}$ Doğu boylamları arasında yer alanı, tüm Türkiye'yi kapsamaktadır (Şekil 1). Meteoroloji Genel Müdürlüğü’nden sağlanan 156 istasyona ait 1966-2014 dönemini kapsayan günlük minimum ve maksimum sıcaklık verilerinden yararlanılmıştır. Sıcaklık verilerindeki ekstrem olayların belirlenebilmesi için kullanılan veri setleri günlük ve orijinal verilerden oluşmaktadır. Sıcaklık indislerindeki uzun süreli eğilimleri Mann-Kendall (M-K) trend analizi ile hesaplanarak alansal dağılış desenleri gösterilmiştir.

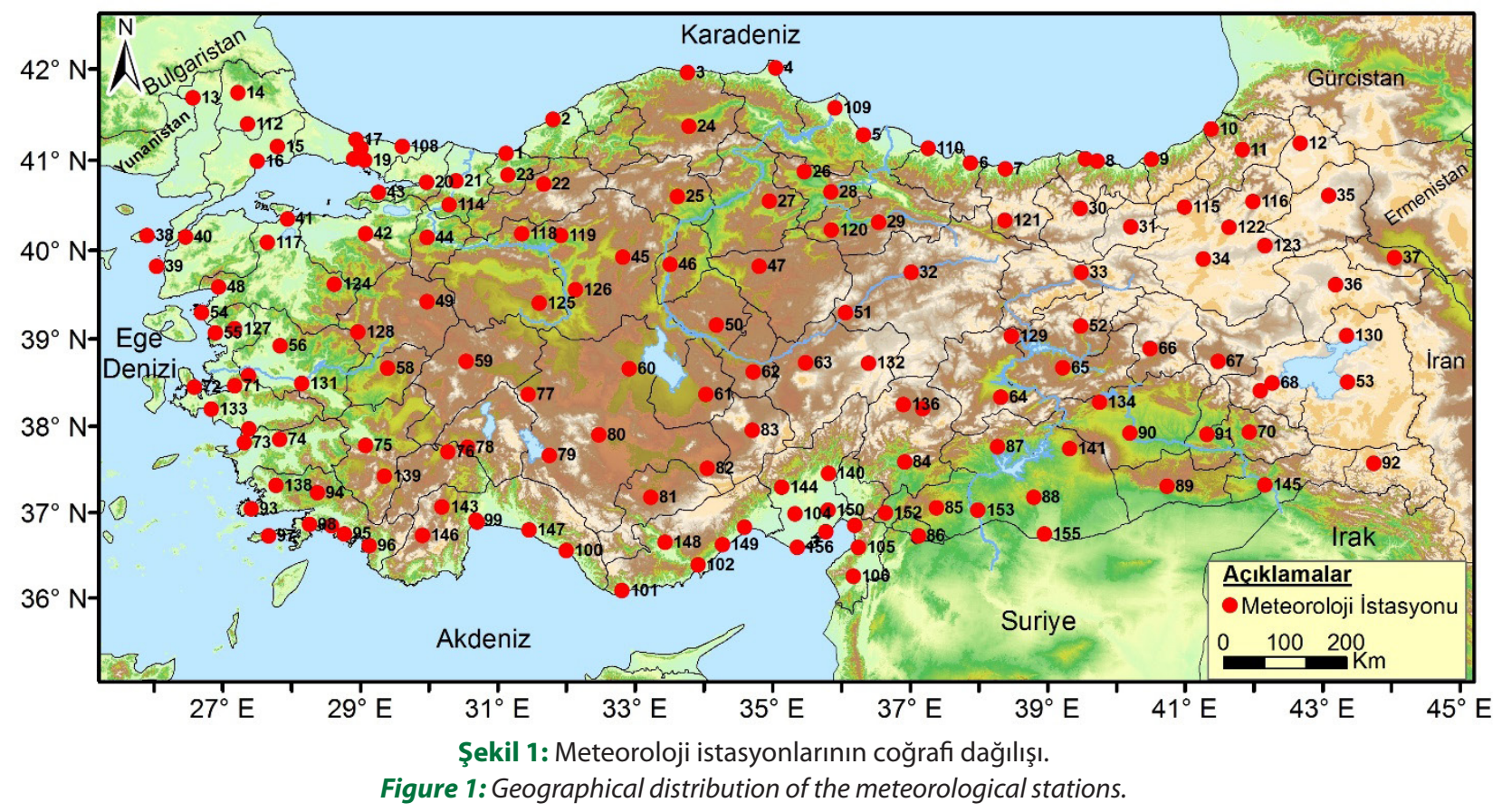


Mann-Kendall rank korelasyon istatistiği tau'nun $(\tau)$ hesaplanmasında, $\mathrm{N}$ ve P'den türetilerek aşağıdaki denklem ile elde edilir. M-K sıra ilişki katsayısı tau'nun $(\tau)$ hesaplamasında, analiz edilen $x_{i}$ elemanlı orijinal gözlem dizisinin yerine, onların küçükten büyüğe dizilmesiyle elde edilen sıra numaralarından oluşan $k_{i}$ dizileri temel alınır. İkinci olarak $P$ istatistiği aşağıdaki gibi hesaplanır;

$P=\sum_{i=1}^{n} n_{i}$

$\tau=\frac{4 P}{N(N-1)}-1$

$\tau$ 'nun anlamlılık sınaması, denklem 3 'deki eşitlikle gösterilir. Hesaplanan $\tau$ değerinin, $\% 5$ ya da $\% 1$ düzeyinde anlamlı ve 0'dan büyük olması durumunda artan, 0'dan küçük olması durumunda ise veri dizisinde azalan yönde bir eğilimden bahsedilebilir (Kendall, 1975; Mann, 1945).

$$
\tau_{(t)}=0 \pm t_{g} \frac{(4 N+10)}{9 N(N-1)}
$$

Mann Kendall sınama sonuçlarındaki istatistiksel anlamlılıklar, $\% 5$ ve \%1 anlamlılık düzeylerine göre belirlenmiştir.

\section{SICAKLIK İNDİSLERİ}

Dünya Meteoroloji Teşkilatı (WMO), ekstrem değerlerin objektif olarak değerlendirilebilmesi için uluslararası kabul gören bir indis dizisi geliştirmiştir (Frich vd., 2002; Klein-Tank ve Können, 2003). Bölgesel ve yerel ölçekli sıcaklık değişkenliği günlük sıcaklık verileri ile hesaplanmıştır. Ekstrem sıcaklık indisleri, yerel ölçekteki sıcaklık değişkenlikleri için bağımsız olarak her bir istasyon için tek tek uygulanmıştır. Uygulanan bu sıcaklık indislerinin temel amacı sıcaklıklardaki alansal tutarlılığ belirlemektir. Çalışmada kullanılan sıcaklık indisleri üç grupta değerlendirilebilir. İlk grup, eşiği belirlenmiş olan indisin frekansinı (Mak $\left.>25, \operatorname{Min}>20, \operatorname{Min}<0^{\circ} \mathrm{C}, \operatorname{Mak}<0^{\circ} \mathrm{C}\right)$ belirlemek için, ikinci grup sıcaklıkların kullanılan indisin yüzde sınırını aşan değerlerin yüzdesini $\left(\operatorname{Min}<1^{\text {st }}, \operatorname{Min}<5^{\text {th }}, \operatorname{Mak}>99^{\text {th }}\right.$, Mak $\left.>95^{\text {th }}, 5 \mathrm{Mak}>95^{\text {th }}, 5 \mathrm{Min}<5^{\text {th }}\right)$ belirlemek için hesaplanmıştır. Üçüncü grup ise sicaklık değişimini (Eks mak $\left.-E_{\text {min }}, G S G\right)$ hesaplamak için kullanılan indislerdir. İklim değişikliği etkilerinin gözlenebildiği bu indis dizileri ile günlük sıcaklıklara ait indisler hesaplanmıştır. Çalışmada, sıcaklıklar için uygulanan indisler Tablo 1'de liste halinde sunulmuştur.

\subsection{Yaz Günleri $\left(\mathrm{T}_{\mathrm{mak}}>25^{\circ} \mathrm{C}\right)$}

Günlük maksimum sicaklıkların $25^{\circ} \mathrm{C}$ üzerinde olduğu günlere yaz günü denir. Yaz günü indisleri, yaz mevsimi (Haziran-Temmuz-Ağustos) maksimum sicaklık verilerine uygulanmıştır. Türkiye'de en büyük yaz günü sayısı ülkenin güney kıyıları ile güneydoğusunda bulunur. Bu alanlarda, 19662014 döneminde ortalama 85-90 yaz günü yaşanırken, Türkiye'nin kuzeydoğusundaki yüksek platoluk ve dağlık alanlarda bu değer 55 güne kadar düşer. Yaz günü indisi sayı olarak, 2001, 2003, 2006, 2008 ve 1998 yıllarında en yüksek değerleri göstermiştir. Yaz günü indisinin en düşük olduğu yıllar ise sırasıyla 1984, 1976, 1967, 1968 ve 1983 yıllarıdır. Türkiye genelinde yaz günü sayılarının 1966-2014 dönemine ait ortalamaları güneyden kuzeye doğru azalır. En büyük yaz günü sayıları Güneydoğu Anadolu Bölgesi ve Türkiye'nin

Tablo 1: Çalışma kapsamında kullanılan sıcaklık indisleri (Alexander vd., 2006; Frich vd., 2002; Klein-Tank ve Können, 2003). Table 1: Temperature indices used in the study (Alexander, et al., 2006; Frich, et al., 2002; Klein-Tank, \& Können, 2003).

\begin{tabular}{lll}
\hline Sıcaklık İndisi & Açıklama & Tanım \\
\hline Mak $>25$ & Maksimum sıcaklığın $>25^{\circ} \mathrm{C}$ olduğu günler & Yaz günü \\
\hline Min $>20$ & Minimum sıcaklığın $>20^{\circ} \mathrm{C}$ olduğu günler & Tropikal gece \\
\hline Min $<1^{\text {st }}$ & Minimum sıcaklığın $<1^{\text {st }}$ yüzdebirlik olduğu günler & Ekstrem serin gece \\
\hline Mak $>99^{\text {th }}$ & Maksimum sıcaklığın $>99^{\text {th }}$ yüzdebirlik olduğu günler & Ekstrem sıcak gün \\
\hline Mak $>95^{\text {th }}$ & Maksimum sıcaklığın $>95^{\text {th }}$ yüzdebirlik olduğu günler & Sıcak gün \\
\hline Min $<0^{\circ} \mathrm{C}$ & Minimum sıcaklığın $<0^{\circ} \mathrm{C}$ olduğu günler & Donlu gün sayıları \\
\hline Mak $<0^{\circ} \mathrm{C}$ & Maksimum sıcaklığın $<0^{\circ} \mathrm{C}$ olduğu günler & Buzlu gün sayıları \\
\hline$G S G$ & Aylık maksimum ve minimum sıcaklıklar arasındaki fark & Günlük sıcaklık aralığı \\
\hline
\end{tabular}




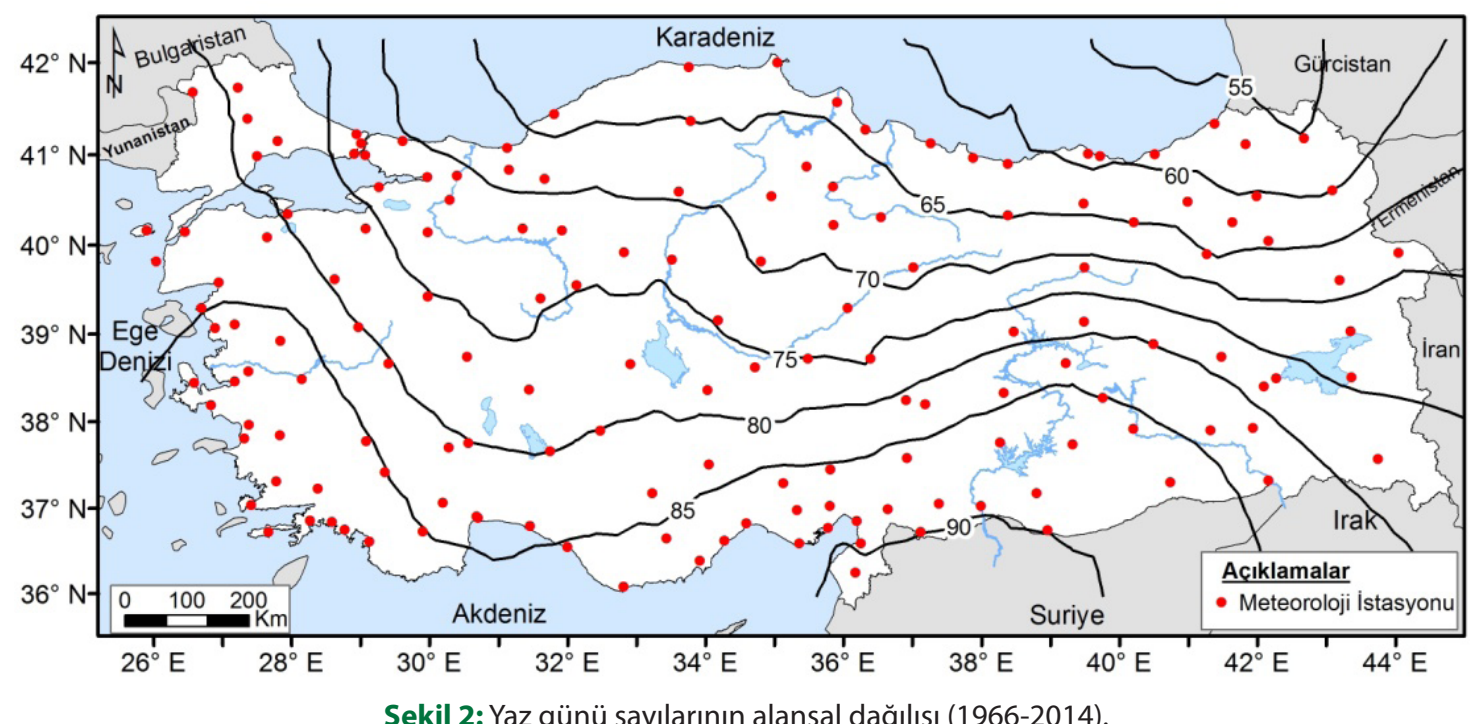

Figure 2: Spatial distribution of the summer day numbers (1966-2014).

güneybatısındaki istasyonlarda gözlenirken, en düşük yaz günü sayıları kuzeydoğu Anadolu'da gözlenmektedir. Hopa, Artvin ve Ardahan istasyonları en düşük yaz günü sayılarına sahip istasyonlardır. Yaz mevsiminde Türkiye'de güneyli dolaşımın etkisi oldukça fazladır. Yüksek sıcaklıklar genellikle atmosferik dolaşıma bağlı olarak Türkiye'nin güneydoğusu ve güneybatısında bu etkiler oldukça belirgindir (Şekil 2).

Mann-Kendall sınamasının Türkiye yaz günü sayılarına uygulanmasıyla elde edilen $\mathrm{u}(\mathrm{t})$ değerine göre, istatistiksel olarak anlamlı bir artış bulunur. Artış eğilimi, 1988 yılındaki önemli değişiklik noktasından sonra 1990'ların başından itibaren anlamlı hale dönüşmüş ve 2000'li y1lların başından itibaren eğilim kuvvetlenmiştir (Şekil 3). Türkiye genelinde yaşanan yaz sıcaklıklarının 1990'lardan bu yana giderek artarken, bu artış eğilimi özellikle de son 10 yılda sistematik bir halde kuvvetlidir. 1960'lardan 1980'li yıllara kadar yaşanan yaz günü sayıları ile 1990 ve sonrası yaz günü değerleri bakımından Türkiye genelinde iki farklı dönemi işaret eder. $\mathrm{Bu}$ değerlendirmeye göre gelecek yaz günü sayılarının en az 10 yılda da farklı olmayacağını giderek ciddi bir artış göstereceğini söylemek mümkündür.

\subsection{Tropikal Geceler $\left(T_{\min }>20\right)$}

Günlük minimum sıcaklık verilerinin, $20^{\circ} \mathrm{C}$ 'nin üzerinde olduğu gecelere tropikal gece denir. Tropikal gece sayılarının en yüksek değerleri sırasıyla 2010, 2012, 2008, 2007 ve 2001 yıllarındadır. Acar-Deniz ve Gönençgil (2013)'e göre, Türkiye'de 2010 yaz mevsimi ekstrem sicaklık anomalilerinin en kuvvetli

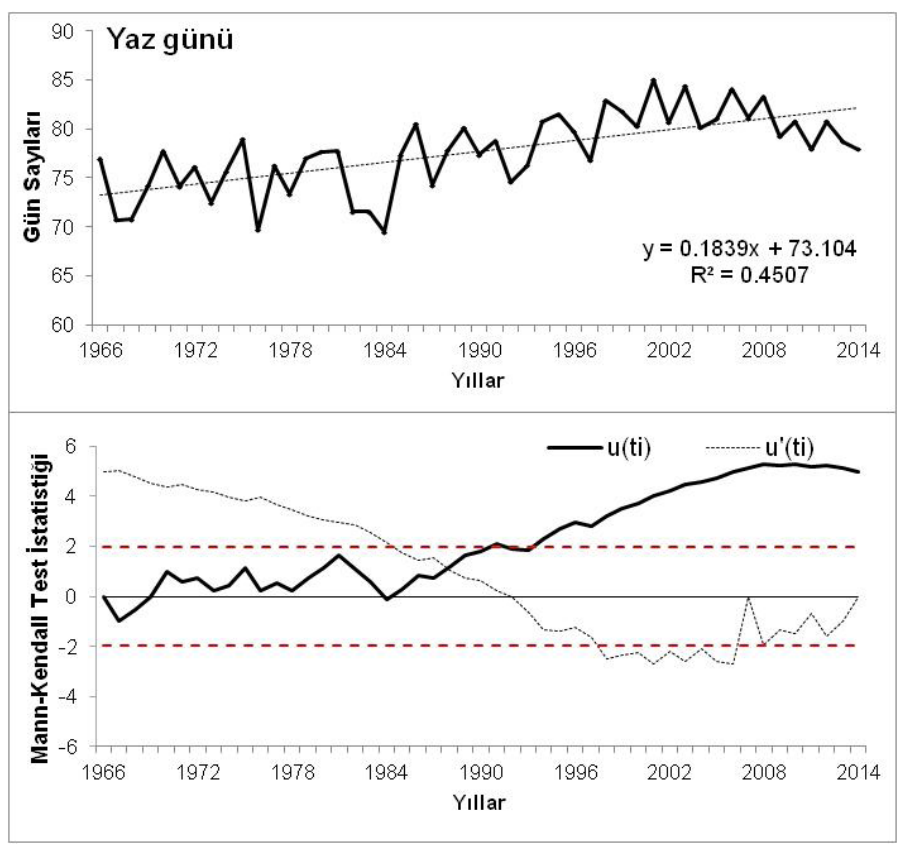

Şekil 3: Mann-Kendall sınamasının ardışık çözümlemesinden elde edilen $u(t)$ ve $u^{\prime}(t)$ değerlerine göre yaz günü sayılarında gözlenen uzun süreli eğilimler. (- - -), normal dağılımın 0.05 anlamlılık düzeyindeki 1.96 olan kritik değeri gösterir.

Figure 3: Long-term trends of the numbers of summer day based on $u$ $(t)$ and $u(t)$ values from the Mann-Kendall rank correlation test. (- - ), shows a critical value of 1.96 at a significance level of 0.05 for the normal distribution.

olduğu yıllardan biridir. En az tropikal gece sirasiyla, 1976, 1984, 1982, 1968 ve 1969 yıllarında yaşanmıştır. Yıllar arası değişimler yaşansa da en yüksek tropikal gece sayıları son 20 yılda gözlenmektedir. 


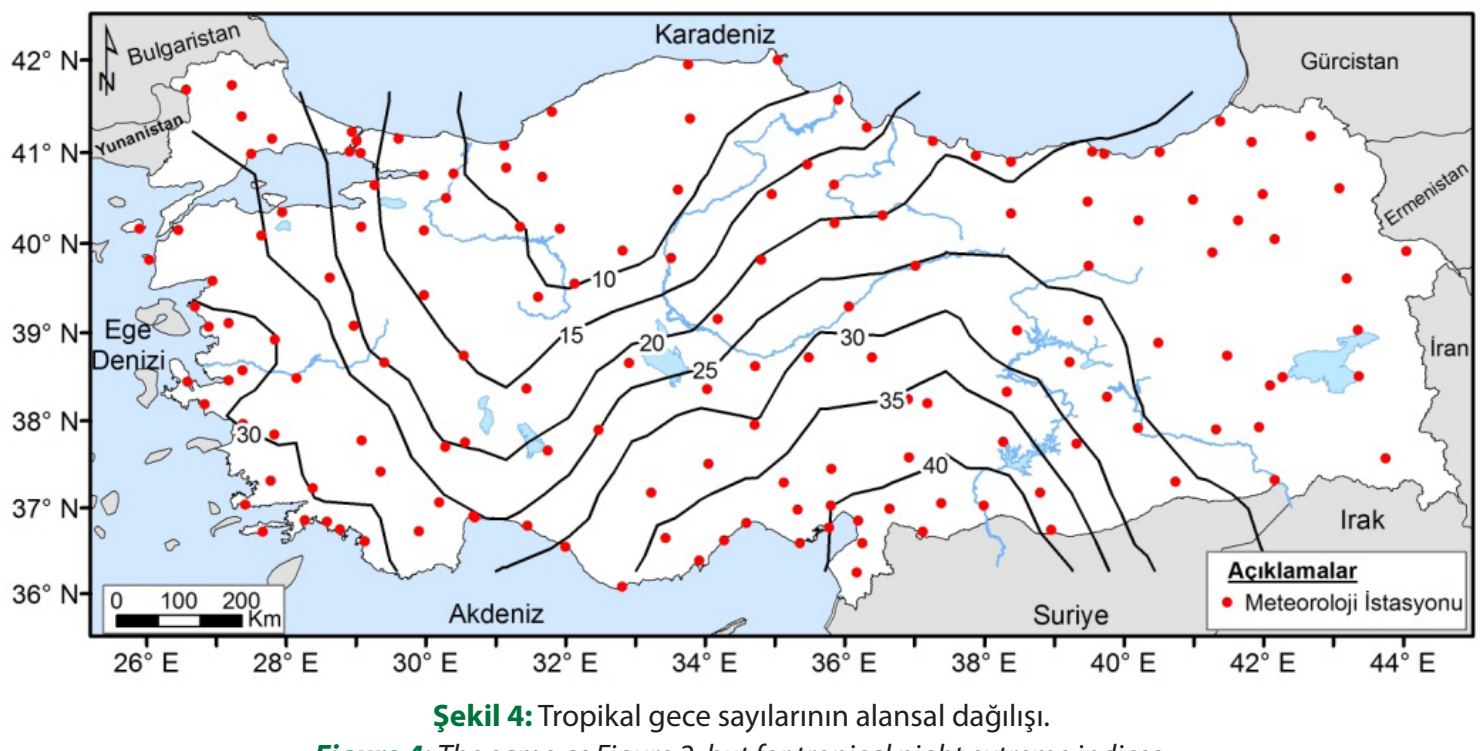

Figure 4: The same as Figure 2, but for tropical night extreme indices.

Türkiye genelinde, istasyonların 1966-2014 dönemine ait ortalama tropikal gece sayıları güneyden kuzeye doğru azalmaktadır. En yüksek tropikal geceler İskenderun körfezi çevresinde gözlenirken, en düşük değerler Batı Karadeniz Bölümü ile Türkiye'nin kuzeydoğusunda gözlenir (Şekil 4).

Tropikal gece sayıları Türkiye genelinde istatistiksel olarak anlamlı bir artış eğilimi içerir. Artış yönündeki bu eğilim 1980'lerin sonlarından itibaren etkili olmaya başlamış ve 1990'ların sonundan itibaren kuvvetli bir 1srara dönüşmüştür. Tropikal geceler için önemli değişiklik noktası 1995 yılıdır. Bu yıldan sonra artış eğilimi anlamlıdır ve son yıllarda da oldukça kuvvetlidir. Tropikal gece sayılarında, 2010 yılı önemli bir yıldır (Şekil 5).

2010 yazındaki sıcak hava dalgası, Türkiye'de pozitif sıcaklık anomalilerinin yaşanmasına yol açmıştır. Tüm Orta ve Doğu Avrupa'da etkisi hissedilen sıcak hava dalgası, kuzeyli dolaşımla Türkiye yüzey hava sıcaklıklarının uzun süreli ortalamadan daha yüksek olmasına neden olmuştur. Özellikle Karadeniz Bölgesi'nin dışında İç Anadolu Bölgesi ve bölgenin kuzeyinde yüksek sıcaklık anomalileri yaşanmıştır (Acar-Deniz ve Gönençgil, 2013).

\subsection{Ekstrem Serin Geceler (Min $<1^{\text {st }}$ )}

Yaz mevsimi minimum sıcaklık verilerinin küçükten büyüğe doğru sıralandığında en uç kısmında kalan, en serin geçen günlerdir. Ekstrem serin geceler minimum sicaklıklarda her istasyon için tek tek hesaplanmıştır. Ekstrem serin

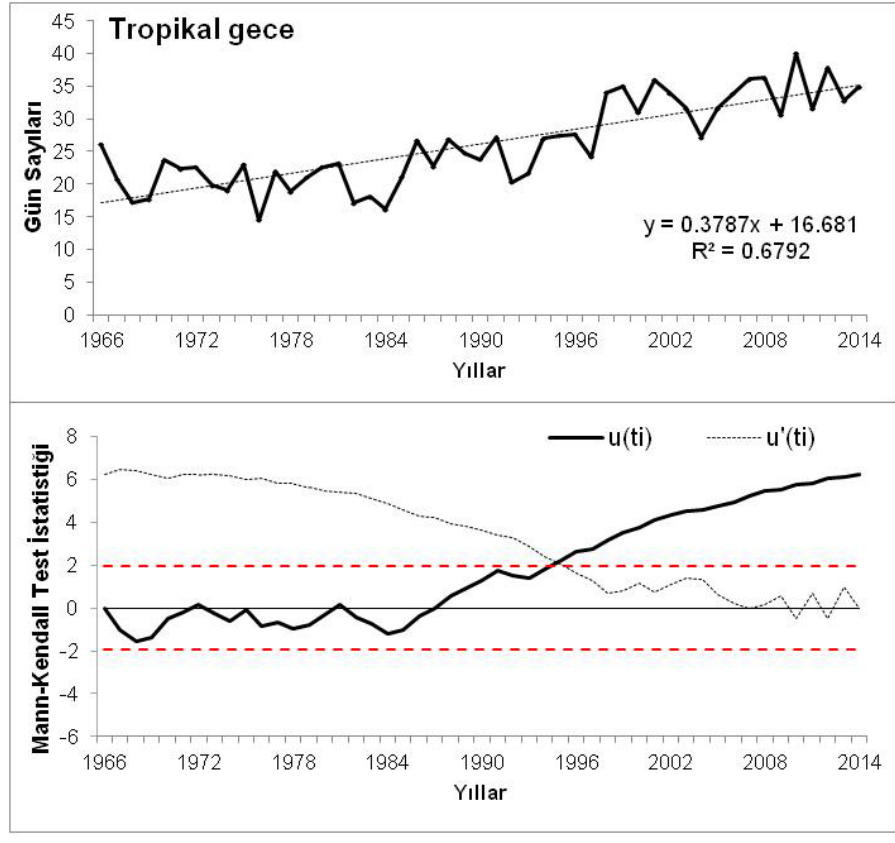

Şekil 5: Tropikal gece sayılarında gözlenen eğilimler. Açıklamalar için Şekil 3'e bakınız.

Figure 5: The observed trends in the number of tropical nights. See Figure 3 for explanations.

gecelerin alansal dağılışında, en düşük değerler Tuz gölünün kuzeyinden Batı Karadeniz Bölümüne doğru uzanan alanda gözlenir. En yüksek değerler ise Türkiye'nin güney kıyıları ile güneydoğusunda yeralır. $\mathrm{Bu}$ alanlar yaz mevsiminde tropikal kökenli dolaşımın etkisi altında kaldıkları için en yüksek değerleri gösterirler. Ayrıca bu durum, minimum sıcaklıklarda gözlenen artışın Türkiye'nin güneydoğusundaki 


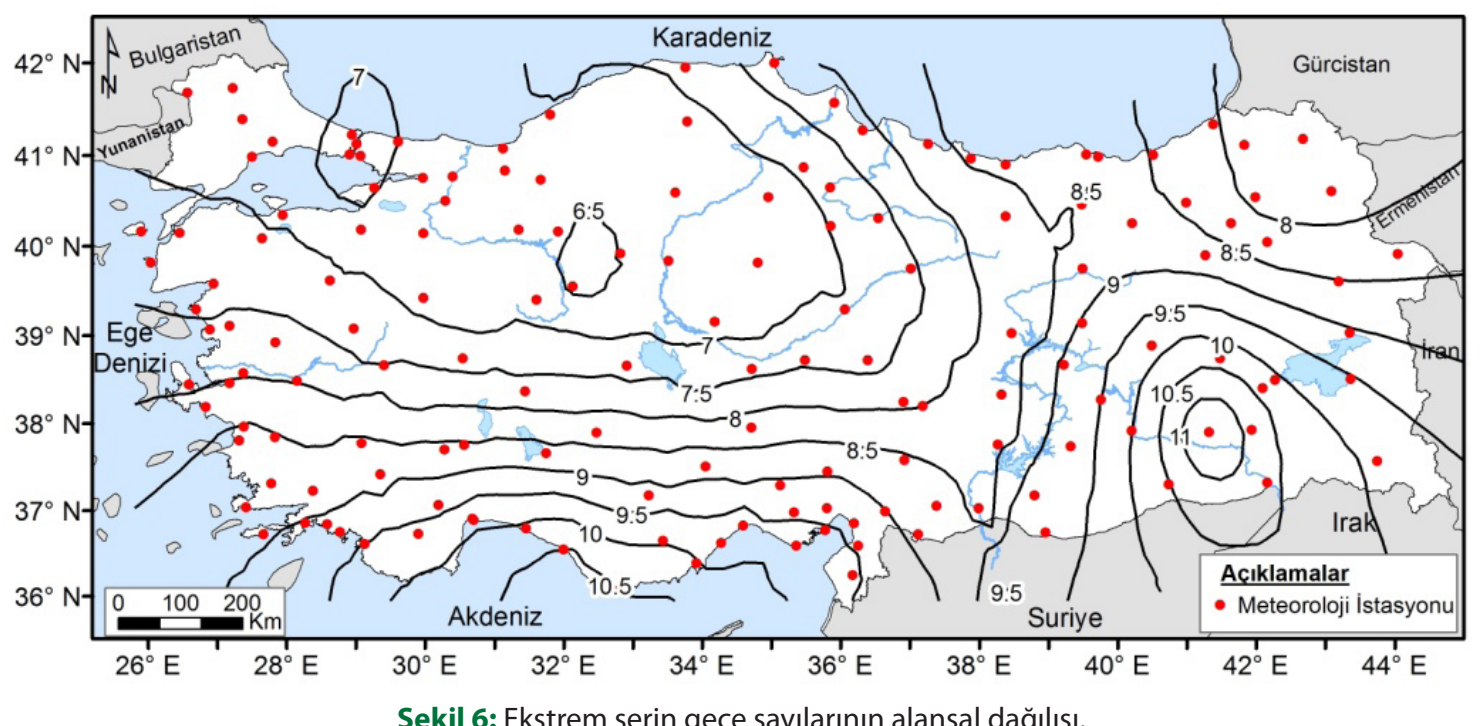

Figure 6: The same as Figure 2, but for Min $<1^{\text {st }}$ extreme indices.

istasyonlarda oldukça kuvvetli olduğunun da bir göstergesi sayılabilir (Şekil 6).

En düşük değerler genellikle Türkiye'nin kuzeybatısında daha çok Trakya çevresinde yaşanır. Bu alan Türkiye'nin sıcak olan güney kesimlerine göre daha serin yaz gecelerine sahiptir ve minimum sıcaklıklardaki artış Türkiye'nin güney kesimindeki kadar kuvvetli değildir. Bu nedenle, yaz mevsimi serin gece sayıları Trakya çevresinde daha az yaşanır.

Ekstrem serin geceler, Türkiye genelinde anlamlı bir azalma eğilimi içerir. Azalma eğilimi için önemli değişiklik noktası 1994 yılıdır. 1980'lerin ortalarından itibaren ekstrem serin gece sayılarında azalma yönünde bir eğilimden bahsedilebilir. 1994 yılından sonra azalma eğilimi istatistiksel olarak anlamlı hale dönüşmüştür ve azalma eğilimi kuvvetli bir ssrar içermektedir (Şekil 7).

Ekstrem serin gece sayıları, Türkiye genelinde en az 2010 yılında yaşanmıştır. Bunda en önemli etkene 2010 yılında yaşanan sıcak hava dalgasıdır. Sıcak hava dalgasının etki alanının geniş olması ve etkili olduğu sürenin uzun olması nedeniyle gece sıcaklıklarında da anlamlı artışlar yaşanmıştır.

Şehirsel alanların etkisi ve yaz mevsiminde bazı yerleşim alanlarının normalin üzerinde bir nüfus miktarına sahip olması şehirsel 1sı adalarının da kuvvetlenmesine yol açmaktadır. Türkiye genelinde yaz mevsimi sıcaklıklarında önemli artış miktarının özellikle yüksek yaz sıcaklık ortalamalarına sahip olan alanlarda daha kuvvetli olduğunu söylemek mümkündür.

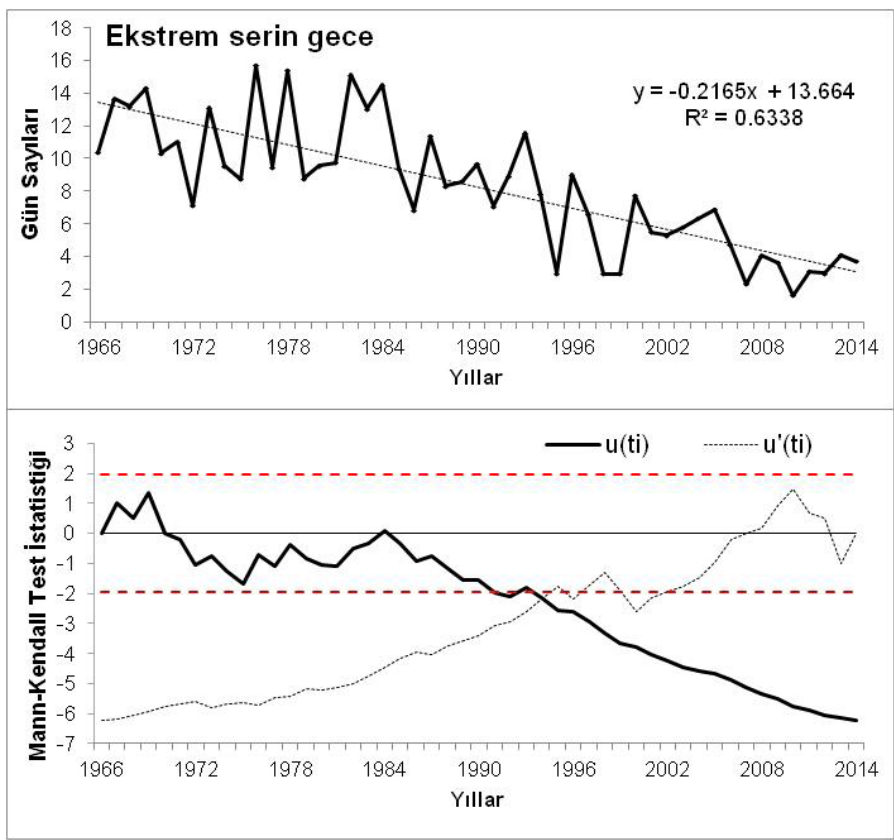

Şekil 7: Ekstrem serin gece indisinde gözlenen eğilimler. Açıklamalar için Şekil 3'e bakınız.

Figure 7: The observed trends in Min $<1^{\text {st }}$ extreme indices. See Figure 3 for explanations.

$\mathrm{Bu}$ durum ayrıca, atmosferik dolaşım koşullarının yaz aylarında daha çok tropikal kökenli hava dolaşımının etkili olduğunun bir göstergesidir.

\subsection{Ekstrem Sıcak Günler (Mak>99 $\left.{ }^{\text {th }}\right)$}

Ekstrem sıcak günler, maksimum sicaklık verilerinin büyükten küçüğe doğru sıralandığında en uçtaki sıcak geçen 


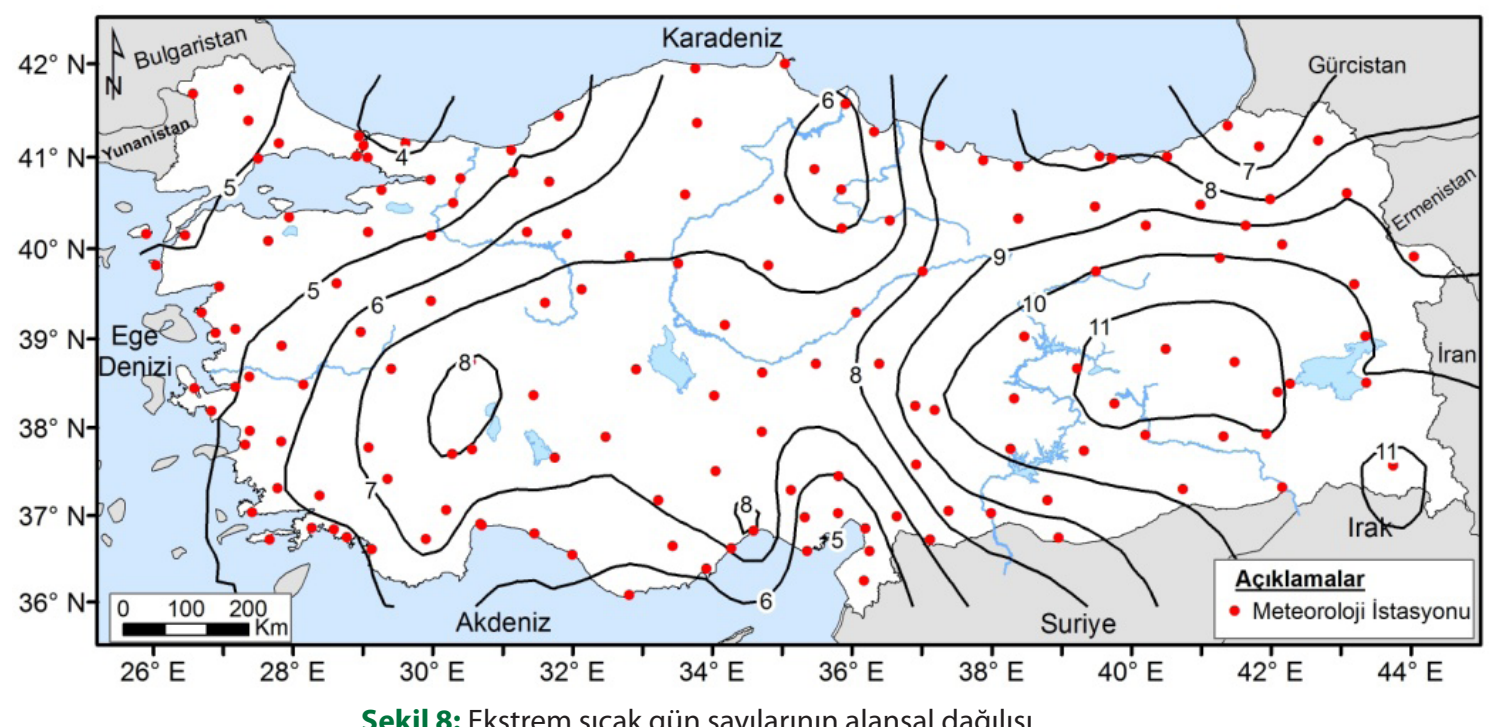

Figure 8: The same as Figure 2, but for Max $>99^{\text {th }}$ extreme indices.

günlerdir. Sicaklık verileri en küçükten en büyüğe doğru sıralandığında, verilerin \%99'unun üzerinde kalan en sıcak günlerdir. Ekstrem sicak gün hesabında kullanılan yüzde periyotlar, maksimum sicaklık verilerinde \%99 altında yaşanan günlerdir. Ekstrem sıcak günlerin en yüksek değerleri, Güneydoğu Anadolu Bölgesi'nde gözlenmektedir (Şekil 8). Yaz mevsiminde bu coğrafyada yaşanan aşırı sıcaklıklar bunun en büyük göstergesidir. Kuzeydoğu Anadolu'da ekstrem sıcak gün değerlerdeki azalma bu alanda yaz mevsiminin daha az sürmesi ve aşırı sıcak günlerin daha az görülmesiyle ilgilidir. Türkiye'nin batısı ve Batı Karadeniz Bölümü'nü kapsayan alanda ekstrem sıcak gün sayıları, Türkiye'nin iç ve doğusuyla kıyaslandığında daha azdır. Bunun en önemli nedeni etezyen rüzgarıdır. Etezyen rüzgarının serinletici etkisi nedeniyle ekstrem sıcak gün sayıları batı kıyılarda azalmaktadır.

Mann-Kendall sınamasının ardışık çözümlemesine göre, ekstrem sıcak gün sayıları için $u(t)$ değeri 4.43 'tür. Ekstrem sıcak gün sayılarında istatistiksel olarak anlamlı artış eğilimleri gözlenir. Türkiye geneli için, ekstrem sıcak gün sayılarındaki önemli değişiklik noktası 1995 yılıdır. 1990’ların sonundan itibaren artış eğilimi anlamlı hale dönüşmüştür. 1970'lerin sonuna kadar uzun süreli ortalamanın altında değerler gözlenirken bu durum 1980'lerden sonra hızla artma yönünde değişmeye başlamıştır. Ekstrem sıcak günler 2000'lerin başından itibaren istatistiksel olarak anlamlıdır. Ekstrem sıcak gün sayılarında son on yıldır ciddi bir artış gözlenmektedir (Şekil 9).

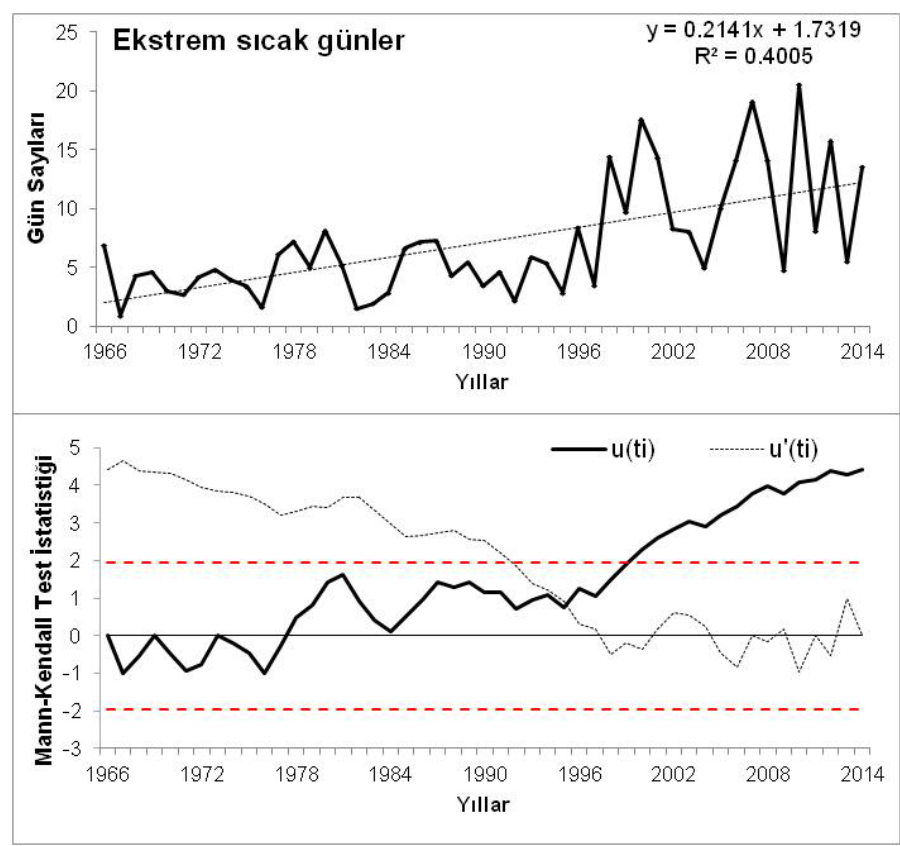

Şekil 9: Ekstrem sıcak gün indisinde gözlenen eğilimler. Figure 9: The observed trends in Max $>99^{\text {th }}$ extreme indices. See Figure 3 for explanations.

\subsection{Sıcak Günler $\left(\right.$ Mak $\left.>95^{\text {th }}\right)$}

Sıcak günler, maksimum sıcaklığın ortalamanın belirlenen eşik değerinin üzerinde olduğu günlerdir. Bu eşik değeri her istasyonunun sıcaklık aralığına göre değişir. Dağılış olarak ekstrem sicak günlere benzemektedir. Güneydoğu Anadolu Bölgesi en yüksek sıcak gün değerlerine sahiptir. Gün sayıları Türkiye'nin batısı ve kuzeydoğusuna doğru azalmaktadır 


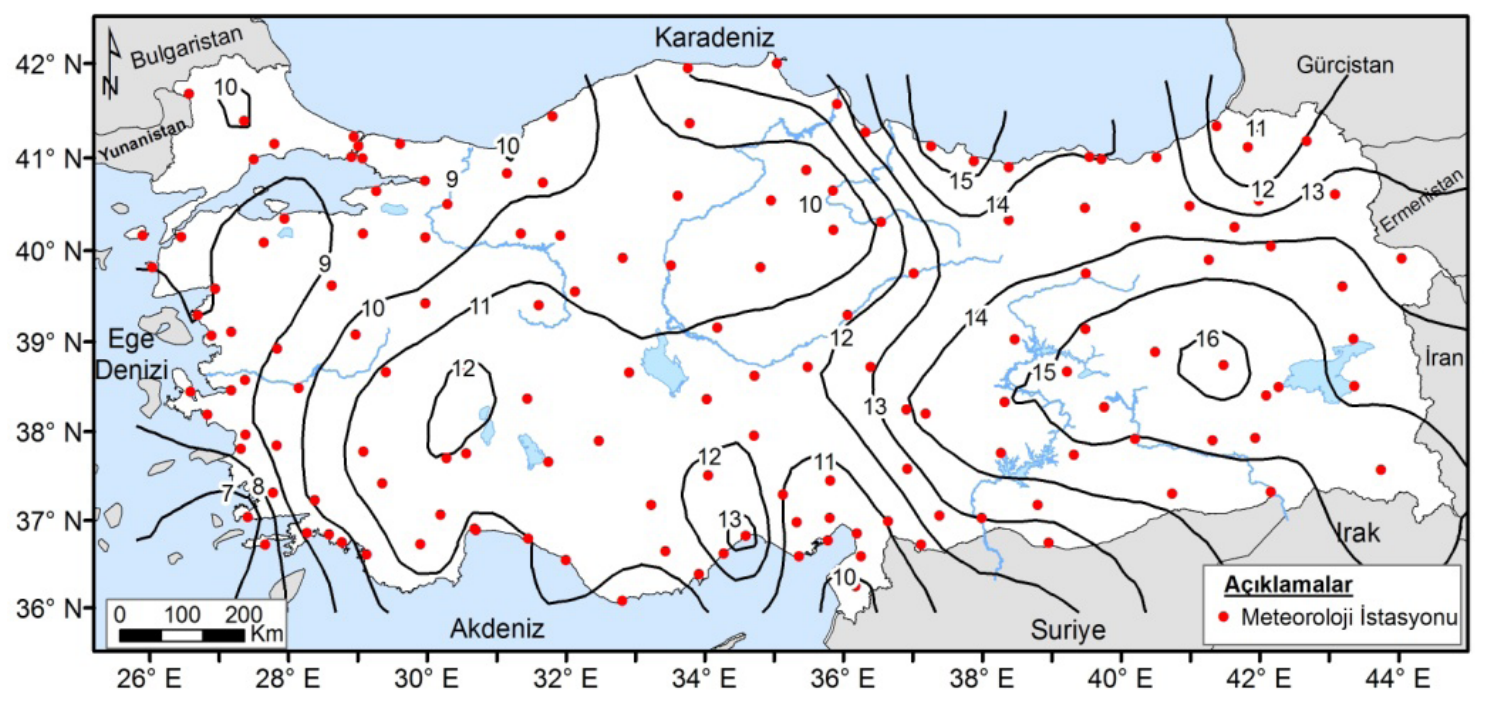

Şekil 10: Sıcak gün sayılarının alansal dağılışı.

Figure 10: The same as Figure 2, but for Max $>95^{\text {th }}$ extreme indices.

(Şekil 10). Sıcak günlerin yıllar arası değişimi incelendiğinde, 1976, 1967, 1982, 1983 ve 1984 y1lları sıcak günleri en az yaşandığı y1llar iken, 2010, 2007, 2000, 2012 ve 2008 y1lları da en fazla yaşandığı yıllardır. Mann-Kendall sınamasına göre sıcak günler için önemli değişiklik noktası 1995 yılıdır. 1999 yılından itibaren sıcak gün sayılarındaki artış eğilimi istatistiksel olarak anlamlıdır. Sıcak gün sayıları, 1990'ların ortalarından itibaren belirgin şekilde artma yönünde bir ısrar içerir (Şekil 11). Bu artış eğilimi, maksimum sıcaklıkların Türkiye genelinde artma eğilimi içermesi ile ilgilidir.

\subsection{Donlu Günler $\left(\operatorname{Min}<0^{\circ} \mathrm{C}\right)$}

Günlük minimum sıcaklıkların, $0^{\circ} \mathrm{C}^{\prime}$ nin altında olduğu anlara donlu gün denir. Donlu gün sayıları Türkiye'nin batısından doğusuna doğru artar. En yüksek donlu gün sayılarına, Doğu Anadolu Bölgesi'nde rastlanır. Özellikle Van'ın kuzeyinde donlu gün sayıları en yüksek değerlere ulaşır. Akdeniz ve Ege Denizi kıyıları ile İstanbul çevresi donlu gün sayılarının en az olduğu alanlardır (Şekil 12).

Donlu günlerin dağılışında denizellik ve yükselti en önemli faktörlerdendir. Denizin 1lımanlaştırıcı etkisini tüm kıyı kuşağı boyunca görmek mümkündür. Kıyıdan iç kesimlere doğru topoğrafyanın etkisiyle donlu gün sayılarında önemli bir alansal değişiklik görülür. Ege kıyılarında denizellik topoğrafyanın etkisiyle daha iç kesimlere kadar ulaşır. Donlu gün sayılarının alansal olarak en yavaş değişim gösterdiği alan Ege Bölgesidir. Karadeniz ve Akdeniz kıyılarında ise topoğrafyanın belirleyici

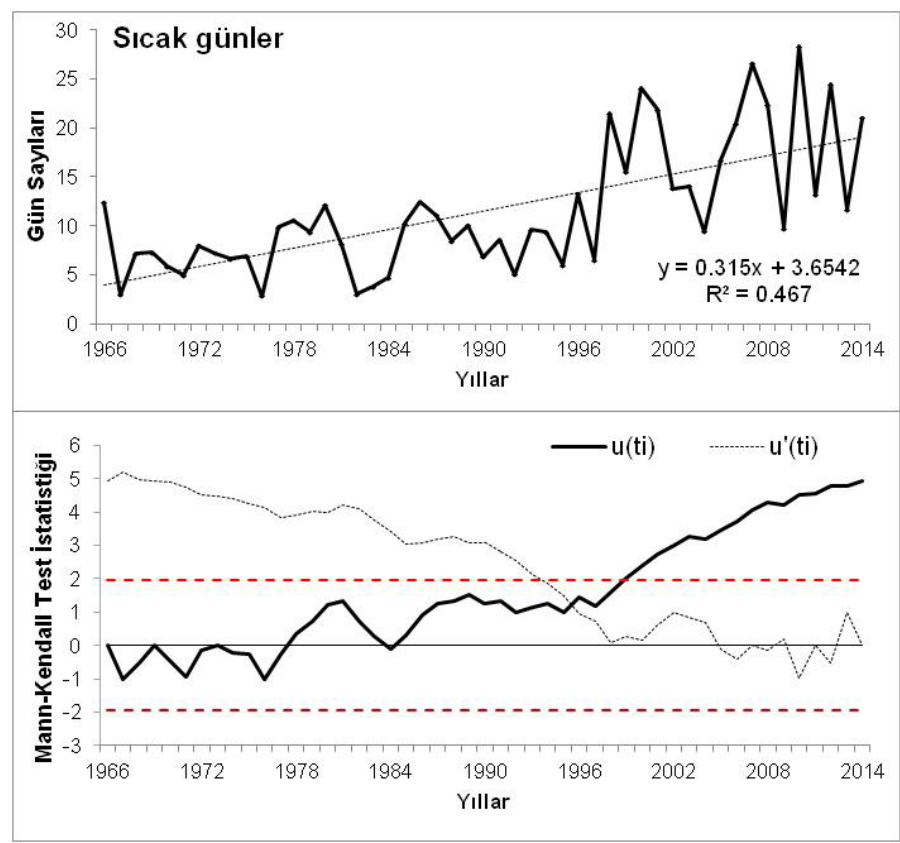

Şekil 11: Sıcak gün ekstrem indisinde gözlenen eğilimler. Açıklamalar için Şekil 3'e bakınız.

Figure 11: The observed trends in Max $>95^{\text {th }}$ extreme indices. See Figure 3 for explanations.

etkisi nedeniyle kıyı kuşağının hemen gerisinde donlu gün sayılarında önemli bir artış görmek mümkündür. İç kesimlerde göl ve akarsuların 1lımanlaştırıcı etkisi olmasına rağmen yükseltinin etkisiyle yaşanan donlu gün sayılarında da önemli artışlar yaşanır. Deniz etkisinin azalması, karasallık ve yükseltinin yanı sıra etkili olan hava kütlelerinin de donlu günler üzerinde önemli bir etkisi vardır. Özellikle son yıllarda artış 


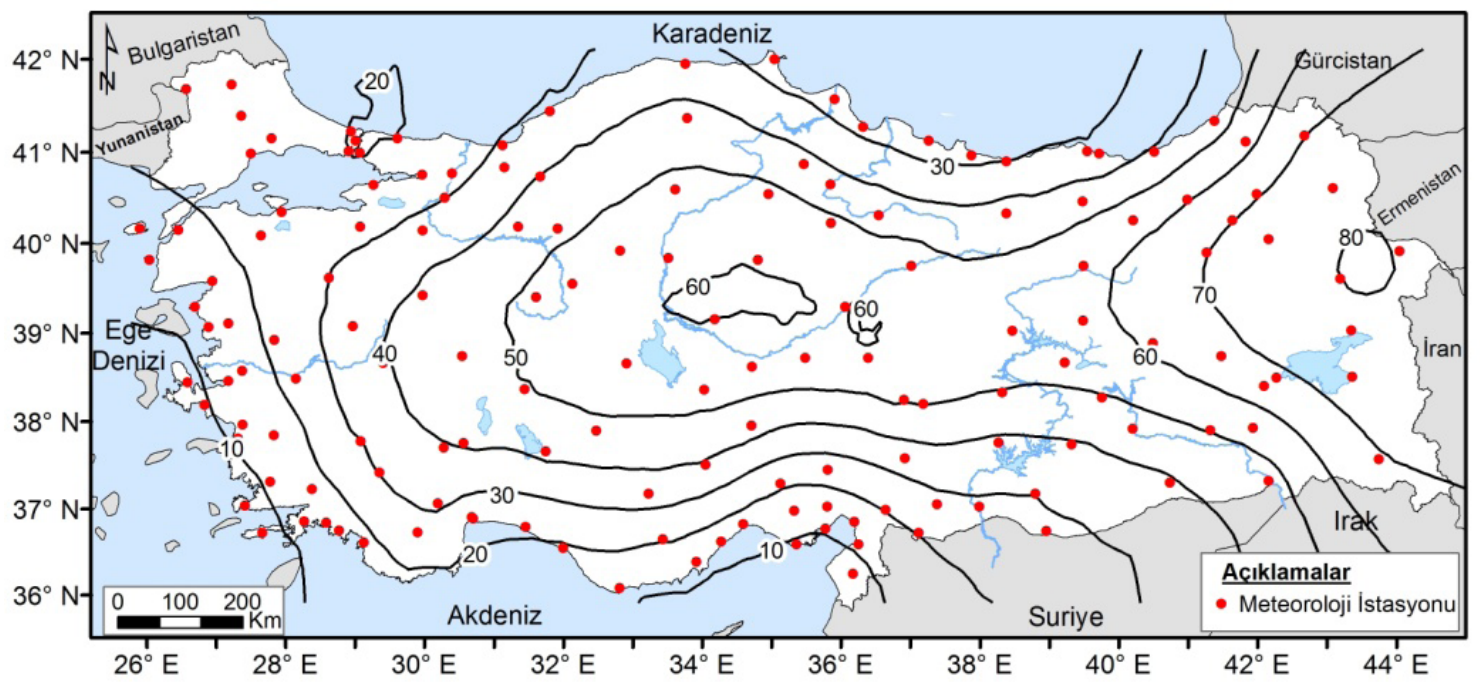

Şekil 12: Donlu gün sayılarının alansal dağılışı.

Figure 12: The same as Figure 2, but for Min $<0^{\circ} \mathrm{C}$ extreme indices.

gösteren ekstrem hava olaylarına (soğuk hava dalgaları) bağlı olarak bunların etkili olduğu sürenin artması donlu günlerin de artmasına neden olmaktadır.

Mann-Kendall sınamasının ardışık çözümlemesine göre, Türkiye genelinde donlu gün sayılarında zayıf bir azalma eğilimi vardır. Azalma eğilimi, istatistiksel olarak anlamlı değildir. Anlamlı olmayan bu azalma 2000'li yılların başından itibaren etkilidir. En düşük don olayları 2010 yılında yaşanmıştır. 1970'ler ve 1990'lara kadar olan dönemde don olayları Türkiye genelinde yüksektir. Son yıllarda, özellikle 1990'lardan sonra sicaklıklardaki (maksimum ve minimum sıcaklıklar) artışlara bağlı olarak soğuk ekstremlerde de azalma görülmektedir (Şekil 13). 1960-1990 dönemlerinde Türkiye genelinde önemli soğuk yıllar yaşanmıştır. Donlu günler, 1966-2014 döneminde en fazla 1992 yılında yaşanmıştır. Bu yılı yüksek donlu gün sayıları ile 1976, 1993, 1972, 1983 ve 2008 yılları izler. Bu soğuk yılların tamamında donlu gün sayıları kış mevsiminde 45 günün üzerindedir. 2004-2008 dönemi ile 2000 ve 2012 yılları dışında Türkiye genelinde donlu gün sayıları 1990'lardan itibaren 40 günün altındadır. Özellikle son yıllarda donlu gün sayısında önceki kış mevsimlerine göre önemli bir azalma olduğu gözlenmektedir.

\subsection{Buzlu Günler $\left(\operatorname{Mak}<0^{\circ} \mathrm{C}\right)$}

Günlük maksimum sıcaklığın, bütün gün boyunca $0^{\circ} \mathrm{C}$ 'nin altında herhangi bir derecede kaldığı günlerdir. Buzlu günler, Türkiye genelinde batıdan doğuya doğru artmaktadır. Buzlu günlerin en fazla görüldüğü yerler Doğu Anadolu Bölgesi, özellikle de Türkiye'nin kuzeydoğusudur (Şekil 14). Bu
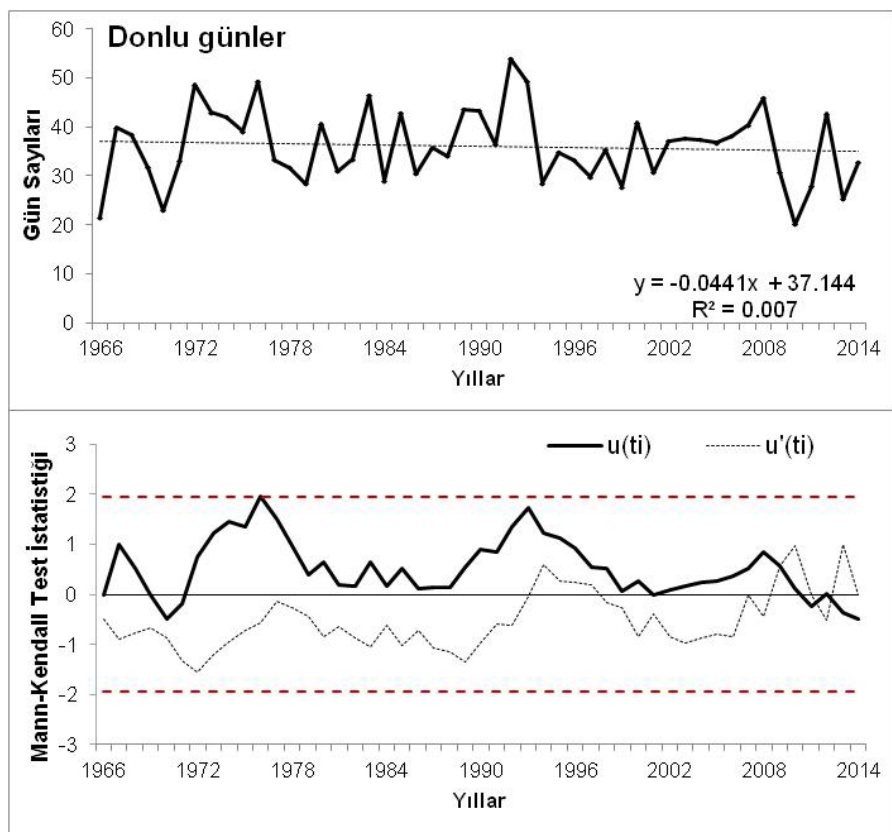

Şekil 13: Donlu gün sayılarında gözlenen eğilimler. Açıklamalar için Şekil 3'e bakınız.

Figure 13: The observed trends in Min $<0^{\circ} \mathrm{C}$ extreme indices. See Figure 3 for explanations.

alanlarda, kış mevsiminin yaklaşı 60 günü buzlu gün olarak yaşanmaktadır. Akdeniz kıyı kuşağı ile kıyı Ege'de yer alan istasyonlarda (Muğla ve Finike dişında) 1966-2014 döneminde neredeyse hiç buzlu gün yaşanmamıştır. Kış mevsiminde etkili olan hava kütlelerinin etkisiyle sıcaklık derecelerinde düşmeler yaşansa da kıyı kuşağındaki istasyonlarda buzlu günler hiç yaşanmamaktadır. Kıyı kuşağından iç kesimlere girildiğinde buzlu günlerde önemli bir artış yaşanır. 


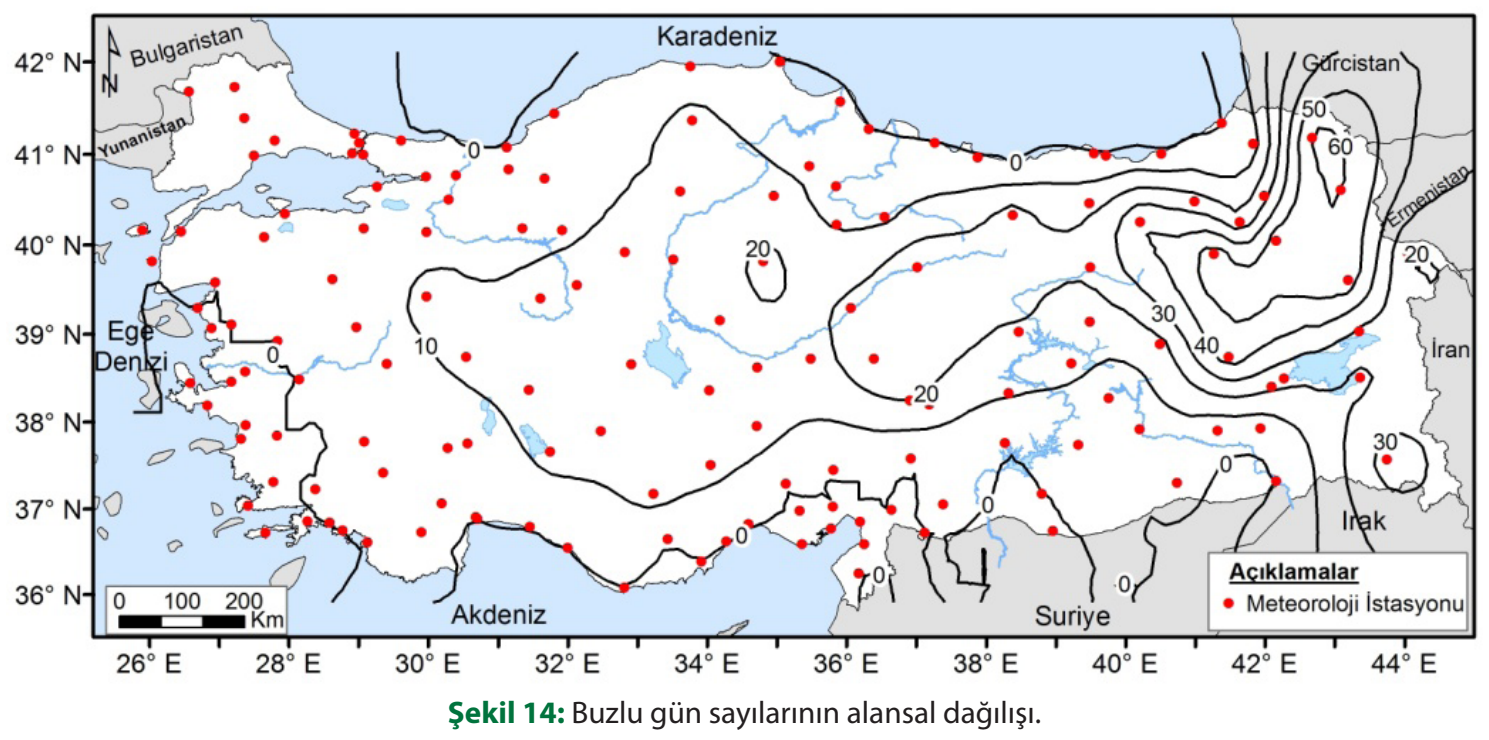

Figure 14: The same as Figure 2, but for Max $<0^{\circ} \mathrm{C}$ extreme indices.

Mann-Kendall sınamasına göre, buzlu gün sayılarında $(\mathrm{u}(\mathrm{t})$ değeri, -1.33) anlamlı olmayan azalma eğilimi vardır. Azalma eğilimi, 2000'li yıllardan itibaren etkili olmaya başlamış özellikle son 5 yıldır kuvvetlenmiştir. Buzlu gün sayılarının en düşük değerlerine sırasıyla 1999, 1984, 2010, 2011 ve 1966 yıllarında rastlanmaktadır. En yüksek buzlu gün sayıları ise 1992, 1972, 1993, 1976 ve 1983 yıllarındadır (Şekil 15).

\subsection{Günlük Sıcaklık Genişliği}

Günlük sıcaklık genişlikleri (GSG), maksimum ve minimum sıcaklık verileri arasındaki farklar alınarak hesaplanır. $\mathrm{Bu}$ çalışmada meteoroloji istasyonlarının hem kış hem de yaz mevsimi için GSG'leri hesaplanmıştır. Bu kapsamda, mevsimlik maksimum ve minimum sıcaklık değerleri arasındaki farklar alınmış ve kış ile yaz mevsimleri ayrı ayrı GSG' ler hesaplanmıştır. Türkiye genelinde, kış mevsimi GSG dizileri, Akdeniz Bölgesi ve Türkiye'nin kuzeydoğusunda en yüksek değerlere sahiptir. En düşük GSG değerleri, Karadeniz kıyı kuşağı boyunca gözlenir. Burada yer alan istasyonların kış mevsimi sıcaklıklarında gece ve gündüz sıcaklık farkları azdır. Karasal etkilerin belirgin olduğu kuzeydoğu Anadolu, Tuz Gölünün güneydoğusu ve Menteşe yöresi gibi engebelik alanlarda GSG değerleri artar. Güney kesimlerde daha 1lıman kış koşulları yaşanmasına rağmen topografyanın gece ve gündüz sıcaklık farkları oluşturmasındaki etkisi büyüktür (Şekil 16). Şekil 15'deki sayılar kış mevsimi maksimum ve minimum sıcaklıkları arasındaki farklardır.

GSG, Mann-Kendall sınamasının ardışık çözümlemesine göre kış mevsiminde Türkiye geneli için zayıf bir artış eğilimi içerir. Bu

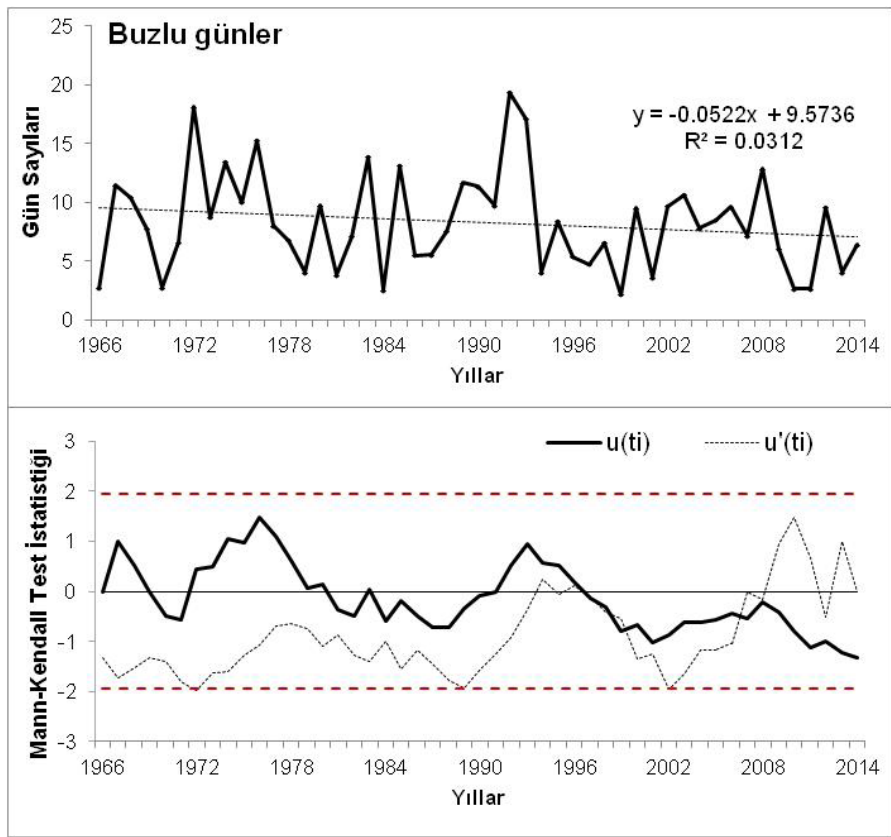

Şekil 15: Buzlu gün sayılarında gözlenen eğilimler. Açıklamalar için Şekil 3'e bakınız.

Figure 15: The observed trends in $\mathrm{Max}<0^{\circ} \mathrm{C}$ extreme indices. See Figure 3 for explanations.

eğilim istatistiksel olarak anlamlı değildir. 1990'ların ortalarından itibaren artış etkisi belirginleşmeye başlamıştır (Şekil 17). Kış mevsiminde GSG değerlerinde gözlenen zayıf artış eğilimi, gece ve gündüz sıcaklıkları arasındaki farklarının artması, büyük ölçüde kış minimum sıcaklıklarındaki artış eğilimleri ile ilgilidir.

Yaz mevsimindeki maksimum ve minimum sicaklıklar arasındaki farklar alındığında kış mevsiminden farklı bir 


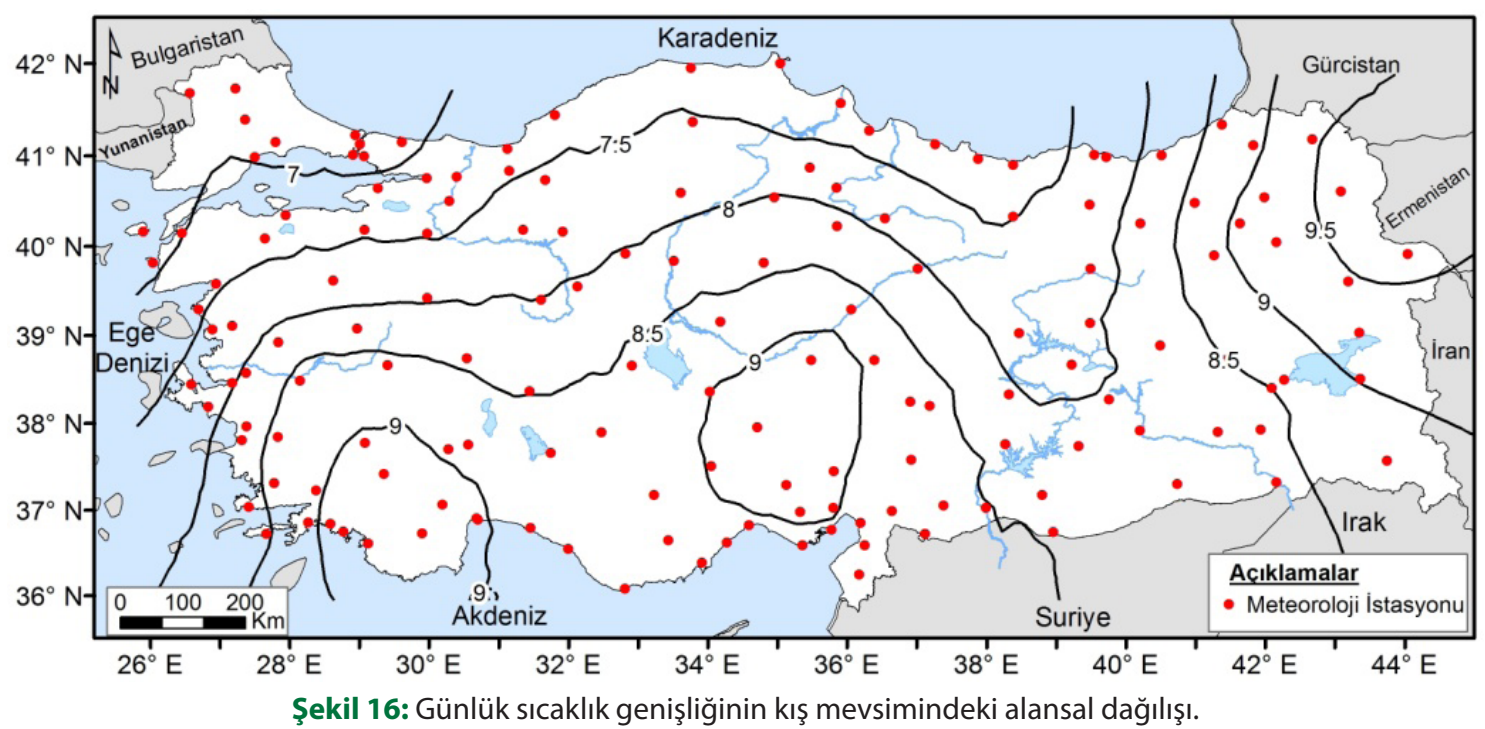

Figure 16: The same as Figure2, but for daily temperature range extreme indices in winter.

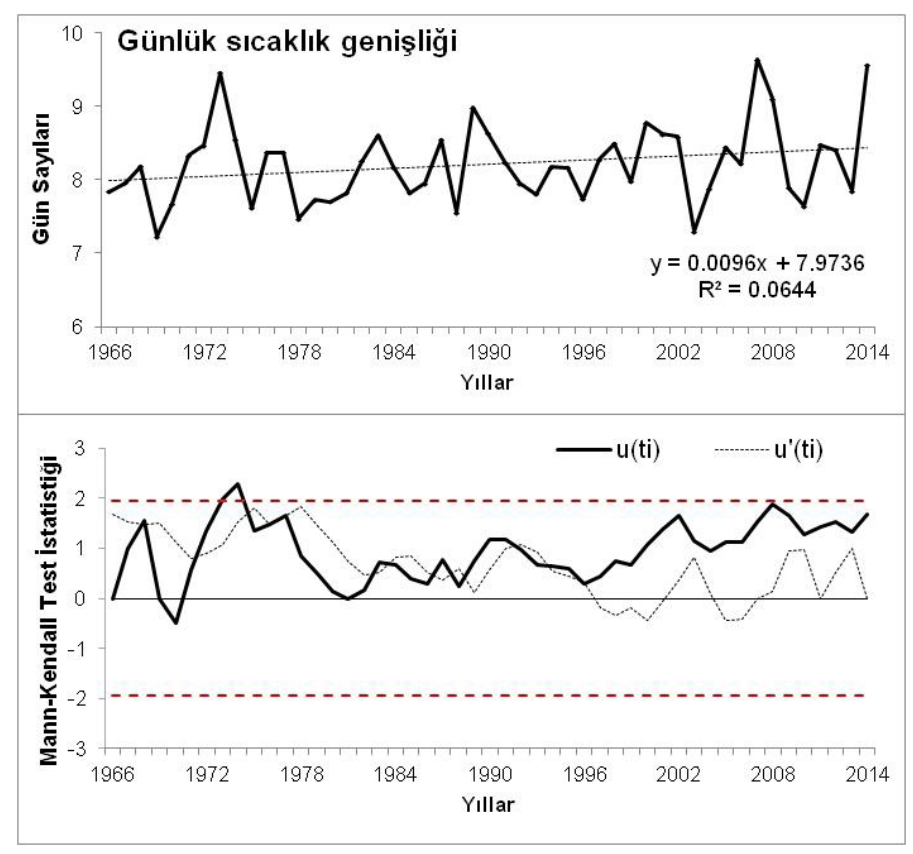

Şekil 17: Kış mevsimi günlük sıcaklık genişliğinde gözlenen eğilimler. Açıklamalar için Şekil 3'e bakınız.

Figure 17: The observed trends in daily temperature range extreme indices in winter. See Figure 3 for explanations.

durum ortaya çıar. Bunun en önemli sebebi yüzeyin 1sınmasıyla birlikte kış mevsimindeki karasallıktan kaynaklanan sıcaklık farklılığının belirgin şekilde azalmasıyla ilgilidir. Yaz mevsimi günlük sıcaklık genişliklerinin, en yüksek değerlerine Güneydoğu Anadolu Bölgesi’nde rastlanır. Ayrıca, Türkiye'nin iç kesimlerinde de GSG değerleri büyüktür. En düşük GSG değerleri ise Trakya'da hesaplanmıştır. Yaz mevsiminde Trakya ve kıyı Ege'deki

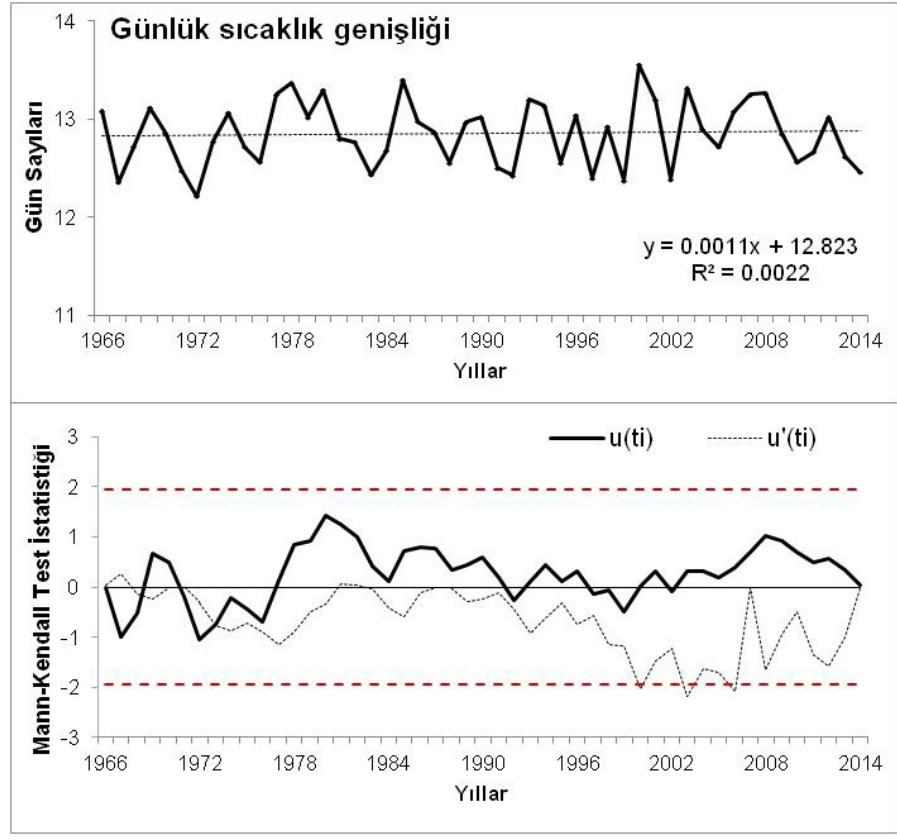

Şekil 18: Yaz mevsimi günlük sıcaklık genişliğinde gözlenen eğilimler. Açıklamalar için Şekil 3'e bakınız.

Figure 18: The observed trends in daily temperature range extreme indices in summer. See Figure 3 for explanations.

düşük GSG’ler büyük ölçüde etezyen rüzgarı ile ilgilidir. Gündüz sıcaklıklarının bunaltıcı etkisinin azalmasıyla, gece ve gündüz sıcaklık farklarının da azaldığı söylenebilir. Yaz mevsimi için yapılan Mann-Kendall sınamasına göre, zayıf artış eğilimleri gözlenmiştir. Yaz mevsimindeki gece ve gündüz sıcaklıklarındaki artış eğilimleri, GSG'lerindeki zayıf artış eğilimlerinin yaşanmasında en önemli etkenlerdendir (Şekil 18). 


\section{BULGULAR}

Çalışma kapsamında Meteoroloji Genel Müdürlüğü’nden sağlanan günlük ortalama, maksimum ve minimum sıcaklık verileri kullanılmıştır. Çalışma kapsamında varılan bulgular özetle şöyledir: 1. Türkiye'nin en dikkat çekici veri dizisi yaz minimum sıcaklıklarıdır. Çalışma kapsamında kullanılan istasyonların büyük çoğunluğunda, yaz gece sıcaklıkları artış eğilimi içerdiği istatistiksel olarak anlamlı inhomojenlikler gözlenir. $\mathrm{Bu}$ durumun ortaya çıkmasında Şehir Isı Adasının (ŞIA) etkisi oldukça büyüktür.

2. Sicaklık verilerine uygulanan indisler, yaz günü, tropikal gece, ekstrem serin gece, ekstrem sicak gün, sıcak gün, donlu gün, buzlu gün ve günlük sıcaklık genişliğidir. Bunlara ilişkin varılan sonuçlar şöyledir:

a) Türkiye genelinde yaz günü ve tropikal gece sayılarında istatistiksel olarak anlamlı bir artış bulunur. Artış yönündeki bu eğilim 1980'lerin sonlarından itibaren etkili olmaya başlamış ve 1990'ların sonundan itibaren kuvvetli bir 1srara dönüşmüştür.

b) Ekstrem serin geceler, Türkiye genelinde anlamlı bir azalma eğilimi içerir. Ekstrem serin gece sayıları, Türkiye genelinde en az 2010 yılında yaşanmıştır. Ekstrem sıcak gün sayılarında istatistiksel olarak anlamlı artış eğilimleri gözlenir. Sıcak gün sayıları, 1990'ların ortalarından itibaren belirgin şekilde artmaktadır.

c) Türkiye genelinde donlu ve buzlu gün sayılarında zayıf bir azalma eğilimi vardır. En düşük don olayları 2010 yılında yaşanmıştır.

d) GSG, kış ve yaz mevsimlerinde Türkiye geneli için zayıf bir artış eğilimi içerir. $\mathrm{Bu}$ eğilim istatistiksel olarak anlamlı değildir. Kış mevsiminde artış eğilimi, kış minimum sıcaklık verilerinde gözlenen artışlarla açıklanabilirken, yaz mevsimindeki minimum ve maksimum sıcaklıklardaki artış eğilimleri ile açıklanabilir.

\section{KAYNAKLAR}

Acar-Deniz, Z., \& Gönençgil, B. (2015). Trends of summer daily maximum temperature extremes in Turkey. Physical Geography, 36(4), 268-281.

Acar-Deniz, Z. ve Gönençgil, B. (2013, Haziran). Ekstrem sıcak yıl: 2010 ve Türkiye yaz dolaşımına etkileri. III. Türkiye İklim Değişikliği Kongresi, s. 453-461, İstanbul.

Alexander, L. V., Zhang, X., Peterson, T. C., Caeser, J., Gleason, B., Klein-Tank, A. M. G., ... Vazquez-Aguirre, J. L. (2006). Global observed changes in daily climate extremes of temperature and precipitation. Journal of Geophysical Research, 111:D05109, doi:10.1029/2005JD006290.

\section{SONUÇLAR}

Çalışma kapsamında elde edilen bulgulara göre Türkiye'de sıcaklıklarındaki değişiklikler özellikle 1990'lı yıllardan sonra belirgin bir değişim gösterir. Yapılan değerlendirmelere göre sıcak geçen günlere ait indislerde artış, serin ya da soğuk geçen günlere ait olan indislerinde ise azalış eğilimi belirgindir. Bu eğilimler yaz günü için 1990'lardan itibaren belirgindir. Tropikal gecelerdeki artış eğilimi yaz günlerinden yaklaşık 5 y1l sonra belirgin hale gelir. Ekstrem serin geceler 1990'ların ortasından itibaren azalma eğilimi gösterirken, ekstrem sıcak günler ve sıcak günler 1990'ların ortalarından itibaren artış yönünde bir eğilim içerir. Donlu ve buzlu günlerde anlamlı olmayan azalma son 10 yılda oldukça belirgindir. Günlük sıcaklık genişliğinde ise özellikle kış mevsiminde belirginleşen zayıf artış eğilimi bu mevsimde yaşanan ekstrem olayların artmasına bağlıdır.

Akdeniz makro iklim alanında yeralan Türkiye geneli için yapılan bu çalışmanın sonuçları ile, Akdeniz Havzası'ndaki yaşanan sıcaklık değişkenlikleri ve ekstrem olayların frekanslarındaki değişkenlikler benzerlik göstermektedir (AcarDeniz ve Gönençgil, 2015; Salman vd., 2017; Zhang vd., 2005). $\mathrm{Bu}$ durum küresel iklim değişikliği süreçleri ile paralellik gösterir. Özellikle şehir içinde kalan meteoroloji istasyonların ortaya çıkan şehir ısı adası etkisini de bu artış sürecinde dikkate almak gerekmektedir. Örneğin yaz gece sıcaklıklarındaki veya diğer bir ifade ile yaz minimumlarındaki artış eğilimi şehir 1sı adası etkisinin önemli bir göstergesidir.

Buna göre Türkiye'de sıcaklık indislerindeki değişim, küresel süreçlerle paralellik gösterir. Şehirleşme, sera gazı salımları ve doğal alan tahribatı gibi antropojenik etmen ve süreçler de bu değişimin daha belirgin, daha kuvvetli hale gelmesine neden olur.

Fernández-Montes. S., \& Rodrigo, F. S. (2012). Trends in seasonal indices of daily temperature extremes in the Iberian Peninsula, 1929-2005. Int $J$ Climatol 32(15), 2320-2332. doi:10.1002/ joc.3399.

Frich, P., Alexander, L. V., Della-Marta, P., Gleason, B., HaylocK, M., Klein-Tank, A. M. G., ... Peterson, T. (2002). Observed coherent changes in climatic extremes during the second half of the twentieth century. Clim Res, 19, 193-212.

Gönençgil, B. (2008). Doğal süreçler açısından iklim değişikliği ve insan. İstanbul: Çantay Yayınevi. 
Kendall, M. G. (1975). Rank correlation methods. Oxford, England London: Charles Griffin.

Klein-Tank, A. M. G., \& Können, G. P., (2003). Trends in indices of daily temperature and precipitation extremes in Europe 1946-1999. Journal of Climate, 16, 3665-3680.

Luterbacher, J., Dietrich, D., Xoplaki, E., Grosjean, M., \& Wanner, H. (2004). European seasonal and annual temperature variability, trends, and extremes since 1500. Nature 303, 1499-1503.

Mann, H. B. (1945). Non-parametric test against trend. Econometrika, 13, 245-259.

Merino, A., Martin, M. L., Fernandez-Gonzalez, S., Sanchez, J. L., \& Valero, F. (2017). Extreme maximum temperature events and their relationships withlarge-scalemodes: potential hazard onthe Iberian Peninsula. Theorical Applied Climatology, 1-20. DOI 10.1007/ s00704-017-2203-9.

Salman, S. A., Shahid, S., Ismail, T., Chung, E. S., \& Al-Abadi, A. M. (2017). Long-term trends in daily temperature extremes in Iraq. Atmospheric Research, 198, 97-107.
The Intergovernmental Panel on Climate Change (IPCC). (2007). Climate Change 2007 - The Physical Science Basis. In S. Solomon, Qin, D., M. Manning, Z. Chen, M. Marquis, K. B. Averyt, M. Tignor, \& H. L. Miller (Eds.), Contribution of working group I to the fourth assessment report of the intergovernmental panel on climate change. Cambridge, United Kingdom and New York, NY, USA.: Cambridge University Press.

The Intergovernmental Panel on Climate Change (IPCC). (2012). Managing the Risks of Extreme Events and Disasters to Advance Climate Change Adaptation. In C. B. Field, V. Barros, T. F. Stocker, D. Qin, D. J. Dokken, K. L. Ebi, M. D. Mastrandrea, K. J. Mach, G.-K. Plattner, S. K. Allen, M. Tignor, \& P. M. Midgley (Eds.), A special report of working groups I and II of the intergovernmental panel on climate change. Cambridge, UK, and New York, NY, USA: Cambridge University Press.

World Meteorological Organization (WMO). (2016). WMO Statement on the status of the global climate in 2015. WMO-No. 1167. WMO: Author.

Zhang, X., Aguilar, E., Sensoy, S., Melkonyan, H., Tagiyeva, U., Ahmed, N., ... Albert, P. (2005). Trends in Middle East climate extreme indices from 1950 to 2003. Journal of Geophysical Research: Atmospheres 110(D22), 1-12. 